УДК 378.04:159.9:316.6

DOI 22185186.2019.1.04

Олена Коваленко

\title{
ТЕОРЕТИЧНІ ТА МЕТОДИЧНІ ЗАСАДИ ПРОФЕСІЙНОӤ ПЫДГТОВКИ МАЙБУТНІХ ПСИХОЛОГІВ ІЗ СОЦІАЛЬНОЇ ПСИХОЛОГІЇ СТАРОСТІ
}

Складною багатогранною проблемою $є$ підготовка майбутніх психологів до роботи з різними категоріями населення. Її успішне розв'язання залежить від цілісності й узгодженості фахової професійної психологічної підготовки. Психологи повинні бути здатними до професійної роботи з особами, які перебувають у ситуації кризи, відчувають значні труднощі у своєму житті, у пристосуванні до умов суспільства, що постійно змінюється. Зважаючи на такі особливості, відзначимо зростання необхідності оновлення всіх компонентів професійної підготовки психологів i, в першу чергу, навчального процесу, навчальних дисциплін. Тому важливою є мета даного дослідження, пов'язана з обгрунтуванням змісту і методичних засад викладання дисципліни «Соціальна психологія старості» майбутнім психологам.

Особливістю соціальної психології старості є те, що це дисципліна підготовки бакалаврів спеціальності 053 «Психологія» за додатковою спеціалізацією «Соціальна психологія». Студенти ії опановують на четвертому курсі, а тому мають достатній рівень психологічної готовності, викладач спирається на раніше отримані ними психологічні знання, уміння і навички. Мета дисципліни - навчити студентів теоретичним основам і прикладним умінням у галузі соціальної психології старості (пізньої дорослості).

Основними завданнями дисципліни є формування у студентів уявлень і відповідних знань про соціальну психологію старості як міждисциплінарну галузь знань, загальні особливості розвитку людини у старості, вікові зміни особистості в цьому віці, специфіку міжособистісного спілкування старіючої людини, роль сім’і в ії житті, місце людини цього віку в суспільстві, психологічні особливості соціальної адаптації у старості, соціальну активність людини в літньому та старечому віці, специфіку соціальної та психологічної допомоги людині в цей період життя.

Опанування компетенціями з соціальної психології старості передбачає засвоєння таких знань: предмет соціальної психології старості, iї місце в системі наук, соціологічні та психологічні теорії старіння, соціаль-

(с) Олена Коваленко, 2019 38 
на ситуація розвитку в старості, провідна діяльність та новоутворення особистості в цьому віці, закономірності психічного розвитку в геронтогенезі, механізми розвитку особистості у старості; анатомо-фізіологічні особливості старіючої людини, кризи пізньої дорослості, психологічні проблеми смерті та вмирання; види і типи старості та старіння, динаміка різних складових особистості на цьому етапі життя; старіння когнітивної та емоційно-вольової сфер особистості; зміст, структура, механізми, функції, чинники міжособистісного спілкування людини віку пізньої дорослості; чинники, які зумовлюють місце старіючої людини в родині, міжособистісні взаємини осіб пізнього віку з представниками інших поколінь, самотність літньої особистості, місце і роль старої людини в сучасному суспільстві, психологічне благополуччя та задоволеність життям у старості; стереотипізація осіб похилого та старечого віку; ейджизм і геронтофобія; пряма та непряма агресія щодо старих людей; соціальна адаптація особистості в пізньому віці; психологічні проблеми виходу літньої людини на пенсію; психологічні та соціальні проблеми старих осіб у спеціальних закладах; психологічні особливості культурно-дозвіллєвої, волонтерської, суспільно-політичної, релігійної діяльності літніх людей; психологія наставництва у старості; психологічні особливості впливу технологій на літніх людей; зміст і напрями діяльності психолога зі старими людьми (психодіагностика, психопрофілактика, психокорекція, психологічне консультування, психотерапія, психологічна освіта); психологічні особливості надання соціальної допомоги старим людям.

Наступна складова компетенцій передбачає оволодіння такими вміннями: обирати методи соціально-психологічного дослідження старих осіб, порівнювати особистісні особливості жінок і чоловіків у віці пізньої дорослості, виявляти особистісні якості та властивості старіючих осіб, визначати специфіку їхньої самооцінки та мотивації, надавати рекомендації з розвитку особистості у цьому віці, визначати ефективність міжособистісного спілкування літніх людей, виявляти причини проблем і конфліктів у стосунках людей цього віку з близькими та надавати рекомендації $з$ їхнього покращення, аналізувати особливості взаємин літнього подружжя, визначати умови психологічного благополуччя літніх осіб, ураховувати й аналізувати стереотипи щодо осіб цього віку, виявляти чинники соціальної адаптованості старіючих людей, надавати рекомендації з підготовки людини до виходу на пенсію, аналізувати психологічні умови ефективної адаптації людини у спеціальному закладі, надавати літній людині рекомендації щодо оптимальної організації іiї соціальної активності, здійснювати психологічне забезпечення навчання користування старих осіб елек- 
тронними засобами зв'язку й іншими технічними новаціями, здійснювати психологічну підготовку людини до взаємодії зі старими людьми.

Умовою для успішного засвоєння студентами даної дисципліни $є$ опанування ними загальної психології, вікової психології, диференціальної психології, соціальної психології, психологічної служби.

Змістовно соціальна психологія старості складається 3 таких тем: соціальна психологія старості як міждисциплінарна галузь знань; загальна характеристика розвитку людини у старості; вікові зміни особистості у старості; міжособистісне спілкування людини у віці пізньої дорослості; сім'я в житті старіючої людини; особи літнього та старечого віку в суспільстві; психологічні особливості соціальної адаптації у старості; соціальна активність людей у літньому та старечому віці; соціальна та психологічна допомога людині на етапі старості.

Опанування змістом даної дисципліни передбачає такі форми навчання, як лекційні, семінарські та практичні заняття, самостійна та індивідуальна робота; оцінюється модульною оцінкою у 100 балів, які студент накопичує поступово.

Лекція $є$ основним видом навчальних занять, призначеним для викладення теоретичного матеріалу однієї або кількох тем навчальної дисципліни. Лекції з соціальної психології старості є науково обгрунтованим, систематизованим, послідовним викладенням наукової інформації з відповідної теми, яка має бути осмислена й усвідомлена. Вона має чітку та логічну структуру із внутрішньо завершеними частинами, насиченими відповідною термінологією й ознаками. Її мета полягає в закладенні основ наукових знань, ознайомленні з методологією наукового дослідження з соціальної психології старості та забезпеченні науковопедагогічної взаємодії викладача і студентів. Лекція може супроводжуватися груповою дискусією з проблеми, яка розглядається. Її зміст є основою для подальшого опанування студентами навчального матеріалу, виконання самостійної та індивідуальної роботи [4; 5].

Під час читання окремих лекцій доцільним є застосування техніки зворотного зв'язку, встановлення активного діалогу з аудиторією. Це дозволяє активізувати розумову активність студентів $\mathrm{i}$ зумовлює краще засвоєння ними отриманої інформації [3].

Перша лекція для студентів стаціонарного відділення спрямована на їхнє ознайомлення з предметом і завданнями соціальної психології старості, чинниками й умовами розвитку старіючої людини, особливостями старіння нервової системи, змістом кризи літнього віку. Друга лекція передбачає ознайомлення студентів із системою психічних 
явищ особистості у старості, проблемою пошуку смислу життя в цьому віці, динамікою особистісних рис і станів у старості, специфікою самооцінки та самоставлення особистості в пізньому віці, перспективами розвитку особистості у старості. На третій лекції розглядається загальна характеристика міжособистісних стосунків і спілкування старої людини, структура та функції міжособистісного спілкування в пізньому віці, механізми та чинники міжособистісного спілкування літніх осіб, показники різних компонентів міжособистісного спілкування осіб цього віку. Четверта лекція передбачає ознайомлення з проблемою місця і ролі людини літнього віку в сучасному суспільстві, психологічним благополуччям людини в пізньому віці, стереотипізацією людей цього віку, агресивною взаємодією оточуючих із ними. Психологічні особливості соціальної адаптації людини у старості, вихід на пенсію як соціально-психологічна проблема, соціальні та психологічні особливості старих осіб в умовах спеціальних закладів обгрунтовуються на п'ятій лекції. Остання, шоста, лекція присвячена ознайомленню студентів зі специфікою діяльності психолога 3 людьми, які знаходяться у періоді пізньої дорослості; особливостями діагностикокорекційної, консультативної, психотерапевтичної роботи психолога 3 особами літнього та старечого віку; специфікою та принципами надання соціальної допомоги старим людям; характеристикою психологічної підготовки людини до взаємодії зі старими людьми.

Семінарські заняття з соціальної психології старості $є$ формою навчального заняття, яке передбачає самостійне здобуття знань переважно у позааудиторний час із використанням різноманітних джерел із подальшим обговоренням наслідків цієї роботи в аудиторії. Семінарське заняття розвиває самостійність мислення і творчість. Під час семінарських занять передбачається вища активність учасників, коли здійснюється обговорення попередньо визначених питань у формі дискусії, бесіди, заслуховування й аналізу реферативних доповідей.

На семінарських заняттях зі студентами стаціонарного відділення обговорюються питання загальної характеристики розвитку людини у старості, вікових змін особистості у старості, специфіки міжособистісного спілкування людини у цьому віці, ролі сім’ї в житті старіючої людини, напрямів соціальної активності людей цього віку, особливостей надання їм соціальної та психологічної допомоги.

Діяльність студентів на семінарських заняттях оцінюється за чотирибальною шкалою («відмінно», «добре», «задовільно», «незадовільно»). Максимальною кількістю балів оцінюється повна і грунтовна 
відповідь, ураховуються доповнення. Отримані оцінки за семінарські заняття далі переводяться у бали - від 0 до 20 [2; 4].

Практичні заняття з соціальної психології старості передбачають детальний розгляд окремих теоретичних положень навчальної дисципліни (у формі бесіди, дискусії) та формування вмінь і навичок їх практичного застосування шляхом виконання студентами відповідно сформульованих завдань. На більшості практичних занять такими завданнями $\epsilon$ необхідність продіагностувати одну літню людину за визначеною методикою, скласти протокол дослідження; останнє заняття передбачає укладання рекомендацій щодо спілкування з людьми віку пізньої дорослості для тих, хто за вимогами професії взаємодіє з ними.

Практичні заняття для студентів стаціонарного відділення присвячені встановленню специфіки особистісних рис і психічних станів літніх осіб, комунікативних якостей їхньої особистості (зокрема комунікативних i організаторських здібностей, емпатійності), соціально-психологічної адаптованості та психологічного благополуччя осіб цього віку.

Діяльність студентів на практичних заняттях також оцінюється за чотирибальною шкалою, ураховується їхня активність у відповідях та виконання практичних завдань. Отримані оцінки за практичні заняття далі переводяться у бали - від 0 до 20 .

Самостійна й індивідуальна робота з соціальної психології старості реалізуються з урахуванням індивідуальних особливостей і пізнавальних можливостей студентів. Такі форми організації навчання спрямовані на поглиблення і розширення знань студентів із питань, визначених у програмі, формування інтересу до пізнавальної діяльності, оволодіння прийомами процесу пізнання, розвиток пізнавальних здібностей. Вони забезпечуються рекомендованою навчальною, науковою та фаховою монографічною і періодичною літературою. Самостійно студенти опановують питання, пов'язані з поглядами представників соціологічних і психологічних шкіл на проблему старіння, методів соціально-психологічного дослідження осіб пізнього віку, психологічних проблем смерті як останньої критичної події в житті людини, типології старості та старіння, ролі сім’ї в житті людини віку пізньої дорослості, соціальної активності осіб цього віку тощо. Оцінювання самостійно опанованих студентами питань здійснюється на семінарських і практичних заняттях, на підсумковому контролі.

Індивідуальна робота з соціальної психології старості передбачає самостійне проведення діагностики десяти осіб літнього віку за визначеними методиками, складання та підготовку узагальнених висновків до 
дослідження. У досліджуваних додатково береться інформація про їхній вік, стать, освіту, вид діяльності у теперішній час, умови проживання (самотній чи не самотній, у місті чи сільській місцевості), задоволеність своїм життям тощо. Для перевірки подаються протоколи дослідження та висновки на окремих аркушах. Виконане завдання оцінюється максимум у 30 балів. Така робота студентів сприяє розвитку їхньої активності й самостійності, що є важливою умовою подальшого самонавчання i caмореалізації в майбутній професійній діяльності [1;4].

Після опанування студентами дисципліни відбувається модульний контроль за допомогою спеціально розроблених кваліфікаційних завдань різних рівнів. Здійснюється даний контроль у вигляді виконання модульної роботи, до якої включено 10 завдань відкритого та закритого типу. Модульна робота оцінюється у 30 балів, за кожну правильну відповідь у роботі нараховується від 2 до 5 балів залежно від складності завдання.

Отже, соціальна психологія старості є дисципліною підготовки бакалаврів спеціальності 053 «Психологія» за додатковою спеціалізацією «Соціальна психологія», яку студенти вивчають на четвертому курсі. Тематично ця дисципліна пов'язана 3 вивченням особливостей соціальної психології старості як міждисциплінарної галузі знань, загальної характеристики розвитку людини у старості, вікових змін особистості у старості, специфіки міжособистісного спілкування людини у віці пізньої дорослості, ролі сім'ї в житті старіючої людини, місця і ролі осіб літнього та старечого віку в суспільстві, психологічних особливостей соціальної адаптації у старості, напрямів соціальної активності людей у літньому та старечому віці, специфіки соціальної та психологічної допомоги людині на етапі старості. Опанування ії змістом передбачає лекційні, семінарські та практичні заняття, самостійну й індивідуальну роботу. Передбачено підсумковий модульний контроль. Діяльність студентів оцінюється модульною оцінкою у 100 балів: по 20 балів - за роботу на семінарських і практичних заняттях, по 30 балів - за індивідуальну роботу (завдання з діагностики) і модульний контроль.

Вивчення цієї дисципліни сприяє оволодінню студентами теоретичними основами і прикладними уміннями в галузі соціальної психології пізньої дорослості, гармонізації процесів їхньої підготовки до реальної професійної діяльності.

\section{Лimepamypa:}

1. Баклицька Т. В. Організаційно-педагогічні умови самостійної роботи студентів у процесі кредитно-модульного навчання. Вісник ЛНУ імені Тараса Шевченка. 2011. № 13 (224). Ч. 1. С. 53-59. 
2. Сфремов С. В. Роль семінарського заняття у навчальному процесі середньої та вищої шкіл. Проблеми фізичного виховання і спорту. 2011. № 3. С. 49-51.

3. Коваленко А. Б. Особливості застосування методів активного навчання у ВНЗ. Психологія: реальність і перспективи. 2013. Вип. 1. С. 13-16.

4. Положення про організацію освітнього процесу в Полтавському національному педагогічному університеті імені В. Г. Короленка. - Полтава : ПНПУ, 2015. - 39 с.

5. Семеног О. Академічна лекція як професійний комунікативний феномен. Естетика і етика педагогічної дії. 2011. Вип. 2. С. 91-101.

\section{References (transliterated and translated):}

1. Baklytska, T. V. Organizatsiino-pedahohichni umovy samostiinoi roboty studentiv $\mathrm{u}$ protsesi kredytno-modulnoho navchannya (Organizational and pedagogical conditions of students' individual work in the process of credit and module training). Visnyk LNU imeni Tarasa Shevchenka (Bulletin of Taras Shevchenko National University of Luhansk). 2011. No 13 (224). Part 1. P. 53-59. (in Ukrainian).

2. Yefremov, S.V. Rol seminarskoho zaniattia u navchalnomu protsesi serednoi ta vyshchoi shkil (Role of seminars in the educational process of secondary and higher schools). Problemy fizychnoho vykhovannia i sportu (Problems of Physical Education and Sports). 2011. No 3. P. 49-51. (in Ukrainian).

3. Kovalenko, A. B. Osoblyvosti zastosuvannia metodiv aktyvnoho navchannia $u$ VNZ (Features of active teaching methods application in higher educational institutions). Psykholohiya: realnist i perspektyvy (Psichology : eality and Prospects). 2013. No 1, P. 3-16. (in Ukrainian).

4. Polozhennia pro orhanizatsiyu osvitnoho protsesu v Poltavskomu natsionalnomu pedahohichnomu universyteti imeni V. H. Korolenka (The manual on the organization of educational process at V. G. Korolenko National Pedagogical University of Poltava). Poltava : PNPU, 2015. 39 p. (in Ukrainian).

5. Semenoh O. Akademichna lektsiya yak profesiinyi komunikatyvnyi fenomen (Academic lecture as a professional communicative phenomenon). Estetyka $i$ etyka pedahohichnoi dii (Aesthetics and Ethics of Pedagogical Action). 2011. No 2. P. 91-101. (in Ukrainian).

Стаття надійшла до редакції 14.11.2018

О. Коваленко

\section{Теоретичні та методичні засади професійної підготовки майбутніх психологів із соціальної психології старості}

У статті розглядаються зміст і методичні засади викладання дисципліни «Соціальна психологія старості» майбутнім психологам, бакалаврам спеціальності 053 «Психологія» 3 додатковою спеціалізацією «Соціальна психологія». Зазначені мета та завдання дисципліни, а також знання й уміння студентів після опанування іiі змістом. Змістовно вона складається iз дев’яти тем: соціальна психологія старості як міждисциплінарна галузь знань, загальна характеристика розвитку людини у старості, вікові зміни особистості у старості, міжособистісне спілкування людини 
у віці пізньої дорослості, сім'я в житті старіючої людини, особи літнього та старечого віку в суспільстві, психологічні особливості соціальної адаптації у старості, соціальна активність людей у літньому та старечому віці, соціальна та психологічна допомога людині на етапі старості. Опанування таким змістом передбачає лекційні, семінарські та практичні заняття, самостійну й індивідуальну роботу. Вивчення дисципліни закінчується підсумковим модульним контролем. Охарактеризовані особливості цих форм організації навчання, подано їхній зміст. Діяльність студентів оцінюється модульною оцінкою у 100 балів. Обгрунтовується система нарахування балів за різні види робіт.

Ключові слова: дисципліна «Соціальна психологія старості», студент, лекція, семінарське заняття, практичне заняття, самостійна робота, індивідуальна робота.

\section{Theoretical and Methodical Basis of Professional Training of Future Psychologists on Social Psychology of Old Age}

The article reviews the content and methodical principles of teaching the subject «Social psychology of old age» to future psychologists, bachelors of specialty 053 «Psychology» with additional specialization «Social Psychology». The goal and tasks of the subject, as well as knowledge and skills of students after mastering its content are revealed. The subject consists of nine chapters: social psychology of old age as an interdisciplinary branch of knowledge, general characteristic of human development in old age, agerelated personality changes in old age, interpersonal communication of a person in old age, family in the life of an aging person, old people in society, psychological features of social adaptation in old age, social activity of people in old age, social and psychological assistance to old person. The study provides the following content lectures, seminars, workshops, individual work. The study of the subject ends with the final module control. The features of these forms of organization of training and their content are presented. Students' activities are assessed by a modular score of 100 points. The system of scoring points for various types of work is substantiated.

Key words: «Social psychology of old age» subject, student, lecture, seminars, practical classes, individual work.

Рецензент - доктор психологічних наук, професор О. А. Кривопишина 